\title{
APLIKASI E-MARKETPLACE MENGGUNAKAN ARSITEKTUR MVVM (MODEL-VIEW-VIEWMODEL) BERBASIS ANDROID
}

\author{
Aryanto ${ }^{1)}$, Edo Arribe ${ }^{2)}$, Rudy Asrianto ${ }^{3)}$ \\ ${ }^{123}$ Prodi Sistem Informasi, Fakultas Ilmu Komputer, Universitas Muhammadiyah Riau \\ ${ }^{1}$ aryanto@umri.ac.id, ${ }^{2}$ edoarribe@umri.ac.id, ${ }^{3}$ rudiasrianto@umri.ac.id
}

\begin{abstract}
The world was shocked by the emergence of a virus at the end of 2019 and this virus was called covid 19. Apart from having an impact on health and problems to overcome, this situation also eventually changed the order of human life. One form of change in the order of human life is in the form of changing the shape of the market where, the market is a meeting between sellers and buyers. Thus, this research tries to study and build an application that bridges market activities that allow it to still occur and can be carried out even in a state of the covid 19 pandemic. This research activity begins by examining user needs which will be built into an e-marketplace and then translated into application form. An Android-based e-marketplace that is considered capable of contributing to seller and buyer transactions during this pandemic. Mvvm as an architecture in android application development is also applied in the development of this e-marketplace application.
\end{abstract}

Keywords: covid 19 pandemic, e-marketplace, mvv-model

\begin{abstract}
Abstrak
Dunia digemparkan dengan kemunculan sebuah virus di akhir tahun 2019 dan virus ini dinamakan covid 19. Selain berdampak kepada kesehatan dan masalah penanggulangannya, keadaan ini juga akhirnya merubah tatanan kehidupan manusia. Salah satu bentuk perubahan pada tatanan kehidupan manusia ini berupa berubahnya pasar yang dulunya secara konvensional menjadi pasar berbasis elektronik. Sehingga, penelitian ini mencoba mengkaji dan membangun sebuah aplikasi yang menjembatani kegiatan pasar yang memungkinkan tetap terjadi dan dapat terlaksana walau dalam keadaan pandemi covid 19. Kegiatan penelitian ini diawali dengan mengkaji kebutuhan pengguna yang akan dibangun menjadi sebuah e-marketplace dan selanjutnya diterjemahkan kedalam bentuk aplikasi e-marketplace berbasis android yang dianggap mampu memberikan kontribusi transaksi penjual dan pembeli dimasa pandemi ini. Mvvm sebagai sebuah aritektur dalam pengembangan aplikasi android juga diterapkan dalam pengembangan aplikasi e-marketplace ini.
\end{abstract}

Keywords: pandemi covid 19, android, e-marketplace, mvv-model

\section{PENDAHULUAN}

Akhir tahun 2019 dunia digemparkan dengan adanya temuan sebuah virus yang telah mewabah ke berbagai negara di dunia. Temuan virus tersebut diberi nama corona, dan karena ditemukannya tahun 2019 virus ini dinamakan juga covid-19 atau kepanjangan dari "corona virus desease 2019". Sehingga, World Health Organization (WHO) pun menetapkan covid-19 sebagai pandemi global [1]. Ternyata virus ini selain menimbulkan masalah kesehatan dan penanggulangannya, virus ini juga berdampak kepada perubahan tatanan kehidupan sosial manusia. Salah satu tatanan perilaku manusia yang ikut terdampak adalah bentuk pasar yang selama ini mempertemukan antara penjual dan pembeli.

Kegiatan jual beli di pasar tradisional akibat dari pandemi virus covid-19 ini terasa lesu, pasar tradisional semakin sepi. Hal ini akibat dari himbauan pemerintah untuk melakukan Pembatasan Sosial Berskala Besar (PSBB) dan enggannya pembeli untuk mengunjungi pasar dikarenakan begitu cepatnya penyebaran penularan virus covid- 19 ini. Karena adanya kebijakan dari pemerintah tersebut, jumlah transaksi dipasar tradional jadi menurun, sehingga omset dari pedagang juga menurun drastis. 
Electronic Marketplace (E-Marketplace) adalah salah satu tekonologi yang dapat dimanfaatkan oleh penjual dan pembeli pada masa pandemi global ini, dan ini merupakan pilihan yang paling tepat agar wabah tidak meluas dan proses transaksi jual beli dapat terus berlangsung. Banyak e-marketplace yang telah ada dan digunakan oleh pelaku pasar, namun belum tentu sesuai dengan dengan kebutuhan. Sehingga kajian akan kebutuhan sistem juga akan sangat diperlukan untuk mewujudkan sebuah emarketplace yang sesuai dengan kebutuhan pelaku pasar di Kota Pekanbaru.

\section{METODE PENELITIAN}

Kerangka kerja digunakan untuk menentukan tahapan-tahapan dalam sebuah penelitian, dan semua tahapan harus dilakukan sesuai dengan perencanaan yang telah dibuat. Oleh karena itu penelitian ini menggunakan metode yang terdiri dari tahap-tahap sebagai berikut:

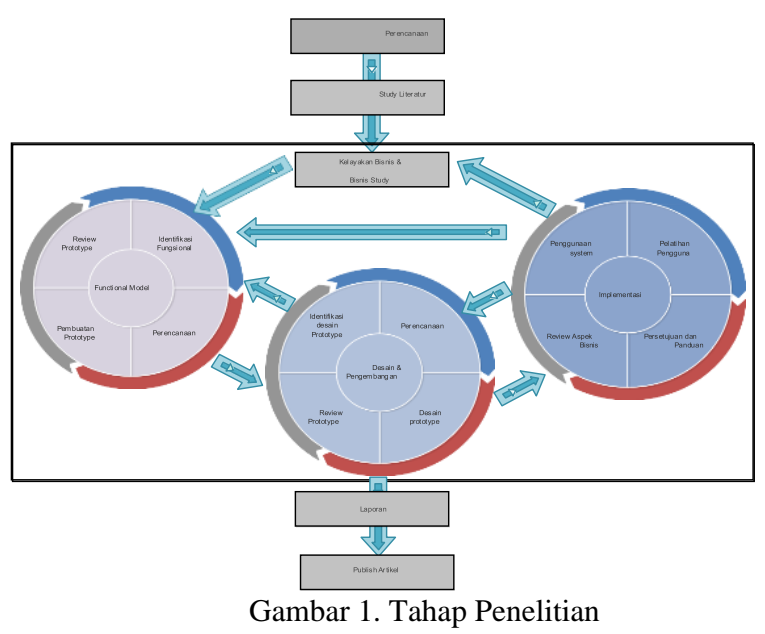

\subsection{Perencanaan}

Semua pekerjaan harus direncanakan, dan penelitian ini diawali dengan perencanaan penelitian yang akan dilakukan. Tahapan ini diawali dengan mencari permasalahan yang ada di tengah masyarakat selaku pelaku pasar di Kota Pekanbaru.

\subsection{Study Literatur}

Setelah permasalahan teridentifikasi, langkah selanjutnya adalah melakukan study literatur dengan mengumpulkan dan memahami literatur terkait permasalahan yang ada. Literatur yang digunakan berupa jurnal, buku teks dan informasi di laman web.

\subsection{Kelayakan Bisnis}

Fase ini akan melakukan analisis terhadap bagaimana pemahaman dan sejauh mana penerapan teknologi informasi oleh pelaku pasar yang ada di kota Pekanbaru. Sehingga dari kesimpulan yang diperoleh, maka akan mudah untuk membangun seperti apa e-marketplace yang sesuai apabila diterapkan di Kota Pekanbaru.

\subsection{Business Study}

Analisis mendalam akan dilakukan dengan cara mewawancarai beberapa pelaku pasar baik itu penjual maupun pembeli yang nantinya akan menjadi pengguna e-marketplace ini. Analisis mendalam ini bermaksud untuk mengenal pasti persyaratan yang harus ada dalam aplikasi e- marketplace yang akan dibangun.

\subsection{Fungsional Model}

Setelah semua permasalahan dan data terkumpul kemudian dirangkum maka tahapan selanjutnya adalah pembuatan prototype dari fungsionalitas e-marketplace yang akan dikembangkan. Tahapan ini akan berulang dilakukan sehingga prototype fungsional modelnya telah selaras dengan keinginan pengguna.

\subsection{Desain dan Pengembangan}

Tahapan berikutnya adalah pembuatan desain dan menerapkan hasil desain kedalam bentuk kode program. Desain yang dibuat berupa desain user interface. Mvv-m model juga digunakan dalam perancangan grafik antarmuka pengguna terkait dengan hasil software yang diharapkan berupa aplikasi berbasis android. Selanjutnya desain basis data. Desain dilakukan berdasarkan fungsional sistem yang telah didapat pada tahap sebelumnya. Desain sistem dilakukan menggunakan Unified Modeling Language (UML). Hasil dari tahapan ini berupa emarketplace yang siap untuk diuji dan diimplementasikan. Sistem yang dibuat direncanakan akan mesra pengguna atau familiar untuk digunakan.

\subsection{Implementasi System}

Setelah tahapan-tahapan analisis dan perancangan sistem dilakukan, pada tahap ini 
dilakukan implementasi dari e-marketplace yang telah dibuat. Implementasi berupa meletakkan kode program ke server sehingga e marketplace ini sudah dapat digunakan.

\section{HASIL DAN PEMBAHASAN}

Pada tahap ini merupakan perancangan aplikasi dan perancangan interface e-marketplace umkm dari hasil analisa sistem.

\subsection{Use Case Aplikasi}

Rancangan use case diagram menjelaskan apa yang akan dilakukan oleh sistem yang akan dibangun dan siapa yang berinteraksi dengan sistem tersebut. Berikut adalah use case dari aplikasi marketplace order baju pintar yang akan dibangun.

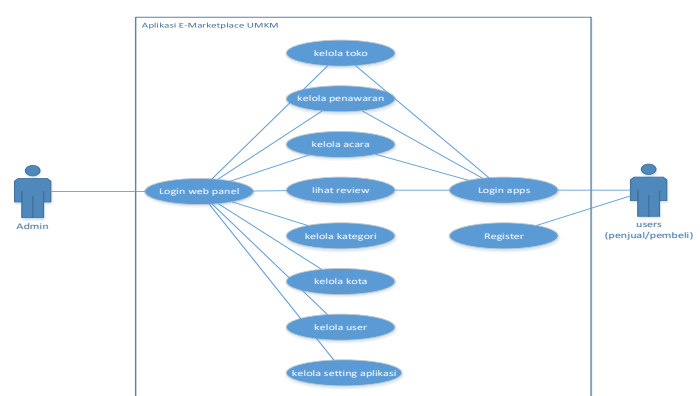

Gambar 2. Usecase Diagram Aplikasi E-Marketplace UMKM

\subsection{Activity Diagram}

Activity Diagram merupakan diagram yang memodelkan alur kerja suatu proses bisnis, sangat mirip dengan flowchart karena memodelkan proses bisnis dari suatu aktivitas ke aktivitas lain atau dari aktivitas ke status. Berikut adalah beberapa activity diagram untuk aplikasi emarketplace umkm.

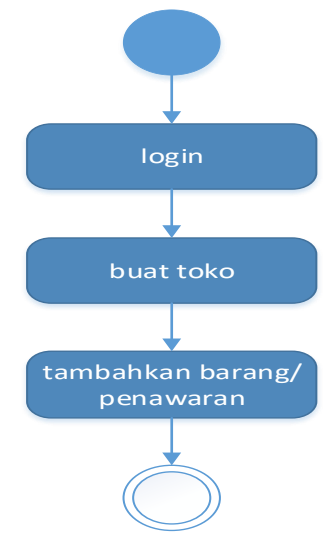

Gambar 3. Activity Diagram membuat toko aplikasi EMarketplace UMKM

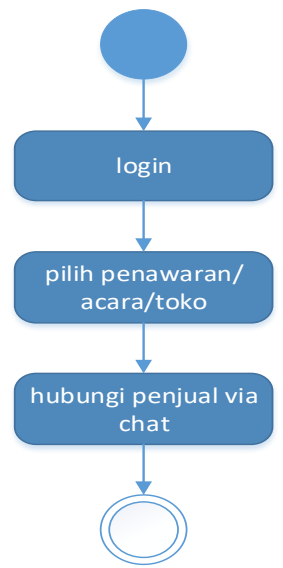

Gambar 4. Activity Diagram transaksi aplikasi EMarketplace UMKM

Tampilan Aplikasi E-Commerce

Berikut adalah interface untuk aplikasi emarketplace umkm. Halaman depan aplikasi ini akan muncul ketika user membuka aplikasi EMarketplace UMKM. Untuk masuk halaman ini tanpa melalui login. Pada halaman ini dapat melakukan pencarian data, menampilkan info terbaru, menampilkan penawaran terbaru dengan gambar dan deskripsi singkat serta ada tombol maps yang menyediakan informasi seluruh data toko dalam bentuk maps. Pada menu profile untuk user membuat akun atau login ke akun.

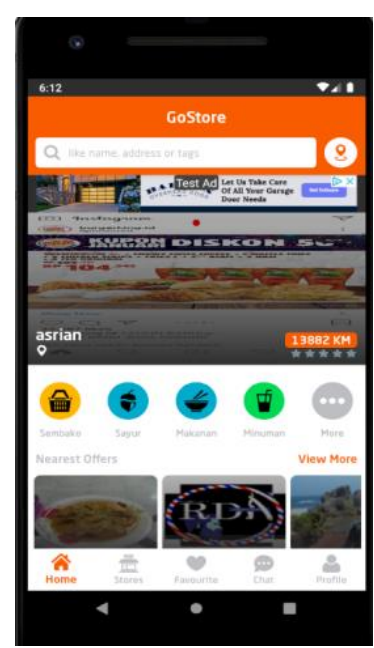

Gambar 5. Tampilan Halaman Pengguna Aplikasi EMarketplace UMKM

Halaman tampilan administrator aplikasi EMarketplace UMKM ini muncul ketika user membuka url E-Marketplace UMKM. Untuk masuk halaman ini harus login sebagai admin. Pada halaman ini dapat mengelola toko, penawaran, acara, review, kategori, kota, user dan setting aplikasi E-Marketplace UMKM. 


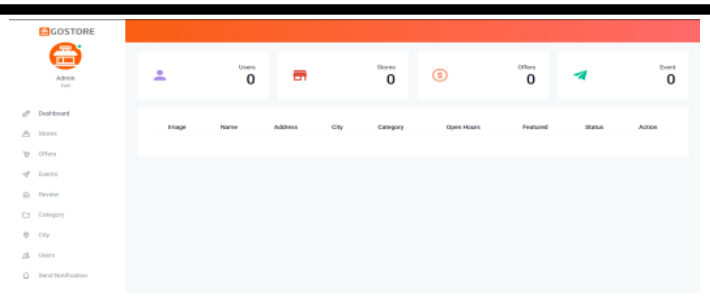

Gambar 6. Tampilan Halaman Administrator Aplikasi EMarketplace UMKM

\section{SIMPULAN DAN SARAN}

Dari hasil kegiatan penelitian ini dapat diambil beberapa kesimpulan sebagai berikut. Dari penelitian ini berhasil diperoleh persyaratan dari pelaku pasar mengenai apa yang betul-betul mereka butuhkan dimasa pandemi ini. Sebuah aplikasi berbasis android pun juga selesai dibuat, menerapkan mvv-model dalam arsitektur perancangan Grafik antarmuka nya, hingga diharapkan aplikasi e-marketplace ini dapat membantu pelaku pasar di kota Pekanbaru untuk menjalani kegiatan mereka sehari-hari.

Penelitian ini dirasa masih terdapat beberapa kelemahan, dimana kelemahan pengembangan sebuah sistem selalu terdapat pada saat memperoleh persyaratan yang sarat akan perubahan. Untuk itu, disarankan kepada peneliti berikutnya dapat melengkapi persyaratan aplikasi sehingga menuju sebuah aplikasi yang lebih baik lagi

\section{DAFTAR PUSTAKA}

[1] WHO. (2020). WHO Director-General's Remark at Media Breafing on 2019-nCov on 11 February 2020. Cited Feb 13th 2020. Available on

https://www.who.int/dg/speeches/detail/who -director-generals remarks-at-the-mediabreafing-on-2019-nCov-on-11-Februari2020. (Feb 12th 2020).

[2] N. Anastasia and I. Handriani, "Aplikasi Sistem Order Jasa Graphic Designer Berbasis Web Pada PT. Decorner," J. Ilm. FIFO, vol. 10, no. 1, p. 87, 2018.

[3] Akhmad Dharma Kasman, 2013, Kolaborasi Dahsyat Android dengan PHP \& MYSQL, LokoMedia, Yogyakarta.

[4] D. Hutauruk, J. F. Naibaho, and B. Rumahorbo, "Analisis dan Perancangan Aplikasi Marketplace Cinderamata khas Batak Berbasis Android," J. Method., vol. 3, no. 1, pp. 242-246, 2017.

[5] M. Susilo, R. Kurniati, and Kasmawi,
"Rancang Bangun Website Toko Online Menggunakan Metode Waterfall," InfoTekJar (Jurnal Nas. Inform. dan Teknol. Jaringan), vol. 2, no. 1, pp. 98-105, 2017.

[6] N. Susanti, "Perancangan E-Marketing Umkm Kerajinan Tas," Simetris J. Tek. Mesin, Elektro dan Ilmu Komputer., vol. 9, no. 1, pp. 717-722, 2019.

[7] Pressman. R.S, Rekayasa Perangkat Lunak :Pendekatan Praktisi Buku I. Yogyakarta: Andi. 2015.

[8] S. Handayani, "Perancangan Sistem Informasi Penjualan Berbasis E-Commerce Studi Kasus Toko Kun Jakarta," Ilk. J. Ilm., vol. 10, no. 2, p. 182, 2018 